\title{
MENINGKATKAN MOTORIK KASAR PADA ANAK MELALUI PERMAINAN ESTAFET PADA ANAK KELOMPOK B \\ Taman Kanak-Kanak Lestari Desa Srikaton Blok V Kecamatan Pondok Kelapa Kabupaten Bengkulu Tengah
}

\author{
Yossie Andriani \\ wahyudianton63@gmail.com
}

H.M. Nasirun

h.m.nasirun@gmail.com

Delrefi D.

an.refi@ymail.com

\begin{abstract}
Permasalahan dalam penelitian ini adalah bagaimana meningkatkan motorik kasar anak melalui permainan estafet pada kelompok B Taman Kanak-kanak Lestari Srikaton Blok V Kecamatan Pondok Kelapa Kabupaten Bengkulu Tengah. Penelitian ini bertujuan untuk meningkatkan motorik kasar anak. Metode penelitian yang digunakan adalah Penelitian Tindakan Kelas. Subjek penelitian yaitu anak kelompok B Taman Kanak-kanak Lestari yang berjumlah 18 orang anak 12 orang anak laki-laki dan 6 orang anak perempuan. Teknik pengumpulan data dengan observasi. Data dianalisis dengan menggunakan rumus ratarata, dan rumus ketuntasan belajar. Hasil penelitian menunjukkan bahwa dengan permainan estafet dapat meningkatkan motorik kasar anak. Pada siklus I mencapai kriteria cukup. Pada siklus II meningkat dengan kriteria baik, sedangkan ketuntasan belajar anak pada siklus I mencapai kriteria baik dan padasiklus II meningkat dengan kriteria sangat baik. Dari hasil penelitian ini direkomendasikan kepada guru jika akan meningkatkan motorik kasar anak, dapat menggunakan permainan estafet.
\end{abstract}

Keywords: Motorik Kasar; Permainan Estafet

\section{PENDAHULUAN}

Menurut UU RI Nomor 20 Tahun 2003 Tentang Sistem Pendidikan Nasional Bab 1 Pasal 1 Ayat 1 , menyatakan bahwa : Pendidikan adalah usaha sadar dan terencana untuk mewujudkan suasana dan proses pembelajaran agar peserta didik secara aktif mengembangkan potensi dirinya untuk memiliki kekuatan spiritual keagamaan, pengendalian diri, kepribadian, kecerdasan, akhlak mulia serta keterampilan yang diperlukan dirinya, masyarakat, bangsa dan negara. Sementara pada UU RI Nomor 20 Tahun 2003 Tentang Sistem Pendidikan Nasional Bab 1 Pasal 1 ayat 14 , menyatakan bahwa pendidikan anak usia dini adalah suatu upaya pembinaan yang ditujukan pada anak sejak lahir sampai dengan usia enam tahun yang dilakukan melalui pemberian rangsangan pendidikan untuk membantu pertumbuhan dan perkembangan jasmani dan rohani agar anak memiliki kesiapan dalam memasuki pendidikan lebih lanjut.

Pendidikan anak usia dini merupakan salah satu bentuk penyelenggaraan 
pendidikan yang menitikberatkan pada peletakan dasar ke arah pertumbuhan dan perkembangan fisik (koordinasi motorik halus dan kasar), Kecerdasan (daya fikir, daya cipta, kecerdasan emosi, kecerdasan spiritual), sosial emosional (sikap dan perilaku serta beragama), bahasa dan komunikasi, sesuai dengan keunikan dan tahap-tahap perkembangan yang dilalui oleh anak usia dini. Maka tepatlah bila dikatakan bahwa anak usia dini adalah usia emas (Golden Age), di mana anak sangat berpotensi mempelajari banyak hal dengan cepat. Masa Golden Age adalah masa penting bagi anak di mana masa ini merupakan awal dari perkembangan masamasa selanjutnya yakni yang mempunyai ciri khas baik secara fisik, psikis, sosial dan moral. Jika perkembangan awal terhambat maka akan menghambat perkembangan selanjutnya, begitu pula sebaliknya. Untuk itu, masa ini perlu perhatian khusus yaitu dengan tidak mengenyampingkan karakter anak yang sesungguhnya, yaitu bermain.

Tujuan Taman Kanak-kanak adalah melakukan stimulasi pendidikan dalam membantu pertumbuhan dan perkembangan jasmani dan rohani sesuai dengan tingkat pencapaian perkembangan anak, mengoptimalkan perkembangan anak secara holistik dan integratif, dan mempersiapkan pembentukan sikap, pengetahuan dan keterampilan anak.

Dalam mencapai tujuan tersebut Taman Kanak-kanak mempunyai tugas untuk mengembangkan enam aspek perkembangan sebagaimana yang tertera pada Permendiknas Nomor 137 Tahun 2014 tentang Standar Pendidikan Anak Usia Dini menyatakan bahwa perkembangan anak yang dicapai merupakan integrasi dalam beberapa aspek perkembangan diantaranya nilai-nilai agama dan moral, fisik, kognitif, bahasa, sosial-emosional, dan seni.

Dalam Permen Diknas Nomor 137 Tahun 2014 tentang Standar Tingkat Pencapaian Perkembangan, menyatakan bahwa pencapaian perkembangan motorik kasar anak usia 5-6 tahun yaitu : (1) Melakukan gerakan tubuh secara terkoordinasi untuk melatih kelenturan, keseimbangan dan kelincahan, (2) Melakukan koordinasi gerakan mata-kakitangan-kepala dalam menirukan tarian atau senam, (3) Melakukan permainan fisik dengan aturan, (4) Terampil menggunakan tangan kanan dan kiri, (5) Melakukan kegiatan kebersihan diri.

Motorik kasar adalah kemampuan gerak tubuh yang menggunakan otot-otot besar, sebagian besar atau seluruh anggota tubuh motorik kasar diperlukan agar anak dapat duduk, menendang, berlari, naik turun tangga dan sebagainya (Sunardi dan Sunaryo, 2007:113-114). Menurut Bambang Sujiono (2007:13) berpendapat bahwa gerakan motorik kasar adalah kemampuan yang membutuhkan koordinasi sebagian besar bagian tubuh anak. Gerakan motorik kasar melibatkan aktivitas otot-otot besar seperti otot tangan, otot kaki dan seluruh tubuh anak. Sedangkan menurut Endang Rini Sukamti (2007:72) bahwa aktivitas yang menggunakan otot-otot besar di antaranya gerakan keterampilan non lokomotor, gerakan lokomotor, dan gerakan manipulatif.

Berdasarkan uraian diatas dapat disimpulkan bahwa motorik kasar adalah kemampuan dalam menggunkan otot-otot besar dan membutuhkan koordinasi gerak tubuh sebagian besar atau seluruh anggota tubuh.

Berdasarkan hasil observasi pada semester ganjil tahu ajaran 2016/2017 yang dilakukan di Taman Kanak-kanak Lestari Srikaton Blok V Kecamatan Pondok Kelapa Kabupaten Bengkulu Tengah, dengan jumlah anak 35 orang anak dimana 21 orang anak laki-laki dan 14 orang anak perempuan, pada saat kegiatan senam ditemukan hanya beberapa anak yang dapat mengikuti kegiatan senam hingga selesai, sebagian anak yang lainnya 
beralasan sulit dalam melakukan gerakan tubuh secara terkoordinasi untuk melatih kelenturan, keseimbangan, kelincahan, dan melakukan koordinasi gerakan mata-kakitangan-kepala dalam menirukan gerkan senam, sehingga mereka tidak mengikuti senam sampai selesai dan anak asik dengan kegiatan anak sendiri. Selain itu gerak motorik kasar yang tampak pada anak tidak berkembang dengan baik, seperti anak belum mampu melakukan kegiatan mengayunkan tangan saat melempar, dan menangkap bola. Oleh karena itu, untuk dapat menstimulasi anak dalam mengembangkan motorik kasar pada anak penulis menggunkan permainan estafet sebagai kegiatan pembelajaran.

Permainan estafet merupakan permainan secara beregu, dimana setiap regu terdiri dari empat orang pelari, setiap pelari mempunyai peran masing-masing dalam permainan (Sunarsih, 2007:69). Peneliti menggunakan permainan estafet ini karena permainan estafet mengasikkan dan menatang bagi anak, karena dalam permainan dilakukan dengan cara dikompetensikan antar regu sehingga anak tertarik dan tertantang dalam melakukan permainan. Selain itu juga dalam permainan ini sangat diperlukan kekuatan gerak tubuh, koordinasi antara mata-tangan dan matakaki, kemampuan anak dalam mengontrol tubuh dan kerjasama yang baik antar tim.

Berdasarkan situasi yang terjadi di Taman Kanak-kanak Lestari Srikaton Blok V Kecamatan Pondok Kelapa Kabupaten Bengkulu Tengah, penulis melakukan penelitian tentang "Meningkatkan Motorik Kasar Pada Anak Melalui Permainan Estafet".

Berdasarkan dari latar belakang di atas, rumusan masalah dalam penelitian ini yaitu:

1. Bagaimana pelaksanaan permainan estafet untuk meningkatkan motorik kasar pada anak kelompok B Taman Kanak-kanak Lestari Desa Srikaton Blok
V Kecamatan Pondok Kelapa

Kabupaten Bengkulu Tengah?

2. Apakah melalui permainan estafet dapat meningkatkan motorik kasar pada anak?

Perkembangan motorik diartikan sebagai perkembangan dari unsur kematangan dan pengendalian gerak tubuh, dan perkembangan tersebut erat kaitannya dengan perkembangan pusat motorik diotak. Sebagaimana yang dikatakan Hurlock, perkembangan motorik adalah perkembangan gerakan jasmaniah melalui kegiatan pusat saraf dan otot yang terkoordinasi (Hurlock,2000:150).

Secara garis besar pembelajaran motorik disekolah meliputi pebelajaran motorik kasar dan halus. Motorik kasar adalah gerakan tubuh yang menggunakan otot-otot besar atau sebagian besar otot yang ada dalam tubuh maupun seluruh anggota tubuh yang dipengaruhi oleh kematangan diri. Sedangkan pembelajaran motorik halus disekolah adalah pembelajaran yang berhubungan dengan keterampilan fisik yang melibatkan otot kecil serta koordinasi antara mata dan tangan.

Motorik adalah segala sesuatu yang berhubungan dengan gerakan-gerakan tubuh. Secara umum, kemampuan motorik terbagi menjadi dua macam, yaitu keterampilan motorik kasar atau gross motor skills dan keterampilan motorik halus atau fine motor skills. Motorik kasar adalah gerakan yang dilakukan dengan melibatkan sebagian besar bagian tubuh. Gerakan motorik kasar memerlukan cukup tenaga dan dilakukan oleh otot-otot besar. Contoh gerakan motorik kasar adalah gerakan berjalan, berlari, melompat dan sebagainya. Sementara motorik halus adalah gerakan yang hanya melibatkan bagian-bagian tubuh tertentu saja dan dilakukan oleh otot-otot kecil.

Berdasarkan kedua keterampilan motorik di atas, tidak semua keterampilan 
motorik akan diteliti. Peneliti akan membatasi penelitian pada keterampilan motorik kasar (gross motor skills). Karena pada dasarnya keterampialn motorik kasar tidak hanya mengoptimalkan kemampuan gerak tubuh saja, namun keterampilan motorik kasar juga dapat melakukan koordinasi mata-tangan dan mata-kaki dan keseimbangan pada anak dalam melakukan sesuatu.

Motorik kasar adalah kemampuan yang membutuhkan koordinasi sebagaian besar bagian tubuh anak. Oleh karena itu, biasanya memerluhkan tenaga karena dilakukan oleh otot-otot yang lebih besar. Pengembangan gerakan motorik kasar juga memerluhkan koordinasi kelompok otototot anak yang tertentu yang dapat membuat mereka dapat melompat, memanjat, berlari, menaiki sepeda roda tiga, serta berdiri dalam satu kaki (Bambang Sujiono:2014.1.13)

Menurut Bambang Sujiono (2014:5.3) pengembangan gerak dasar adalah proses di mana anak memperoleh gerak dasar yang senantiasa berkembang berdasarkan : 1). Proses pengembangan syaraf dan otot yang juga dipengaruhi oleh keturunan, 2). Akibat dari pengalaman gerak sebelumnya, 3). Pengalaman gerak saat ini, 4). Gerak yang digambarkan dalam kaitannya dengan pola gerak tertentu.

Pola gerak dasar adalah bentuk gerakan-gerakan sederhana yang bias dibagi ke dalam 3 (Tiga) bentuk gerakan sebagai berikut : 1). Gerak lokomotor (gerakan berpindah tempat) di mana bagian tubuh tertentu bergerak atau berpinndah tempat, contohnya berjalan, berlari, meloncat, dan lain-lain. 2). Gerak non lokomotor (gerakan tidak berpindah tempat) dimana sebagian anggota tubuh tertentu saja yang digerakkan namun tidak berpindah tempat, contohnya mendorong, menarik, menekuk, memutar. 3). Gerak manipulatif dimana ada sesuatu yang digerakkan, contohnya melempar, menagkap, menyepak, memukul, dan gerakan lain yang berkiatan dengan lemparan dan tangkapan sesuatu.

$$
\text { Menurut Bambang Sujiono }
$$

(2014:12.9-12.10) mengemukakan bahwa indikator motorik kasar dapat diperoleh melalui : a) memantulkan bola besar, bola sedang dan bola kecil (diam ditempat), b) melambungkan dan menangkap bola sambil berjalan atau bergerak, c) memantulkan bola besar, bola sedang dan bola kecil sambil berjalan atau bergerak, d) menangkap dan melempar bola besar, bola sedang dan bola kecil, e) berjalan dengan tumit sambil membawa beban, f) berlari sambil membawa bola dengan seimbang tampa jatuh, g) menendang bola ke depan dan ke belakang.

Adapun usur-unsur pokok dalam pembelajaran motorik disekolah adalah sebagai berikut : 1) Kekuatan 2)Kecepatan 3) Power 4)Ketahanan 5) Kelincahan 6) Keseimbangan 7) Fleksibilitas 8) Koordinasi

Menurut Bambang Sujiono (2014:3.22-3.33) mengemukakan bahwa karakteristik perkembangan gerak motorik kasar pada anak sebagai berikut : 1) Mengekspresikan gerakan dengan irama bervariasi 2) Memanjat dan bergelantungan 3) Melompati parit atau guling 4) Senam dengan gerakan kreativitas sendiri 5) Berlari 6) Melempar dan menagkap bola 7) Berjalan diatas papan titian 8) Berjalan dengan berbagai variasi

\section{METODE PENELITIAN}

Jenis penelitian yang dilgunakan adalah penelitian tindakan kelas (Classroom Action Research). Menurut Arikunto, dkk, (2008:2) penelitian tindakan kelas yaitu penelitian yang dilakukan oleh guru di dalam kelas atau di sekolah tempat ia mengajar dengan penekankan ada penyempurnaan atau peningkatan proses dan praksis pembelajaran. Penelitian ini menggunakan rancangan penelitian tindakan (Classroom Action Research), Secara garis besar terdapat empat tahapan 
yang lazim dilalui dalam penelitian tindakan kelas yaitu (1) perencanaan, (2) pelaksanaan, (3) pengamatan, dan (4) refleksi (Arikunto, dkk, 2008: 16).

Adapun Subjek dalam penelitian ini yaitu kelompok B Taman Kanak-Kanak Lestari Desa Srikaton Blok V Kecamatan Pondok Kelapa Kabupaten Bengkulu Tengah, yang berjumlah 18 orang, terdiri dari anak laki-laki sebanyak 12 orang dan jumlah anak perempuan sebanyak 6 orang.

Prosedur peneletian dalam Penelitian tindakan kelas ini adalah

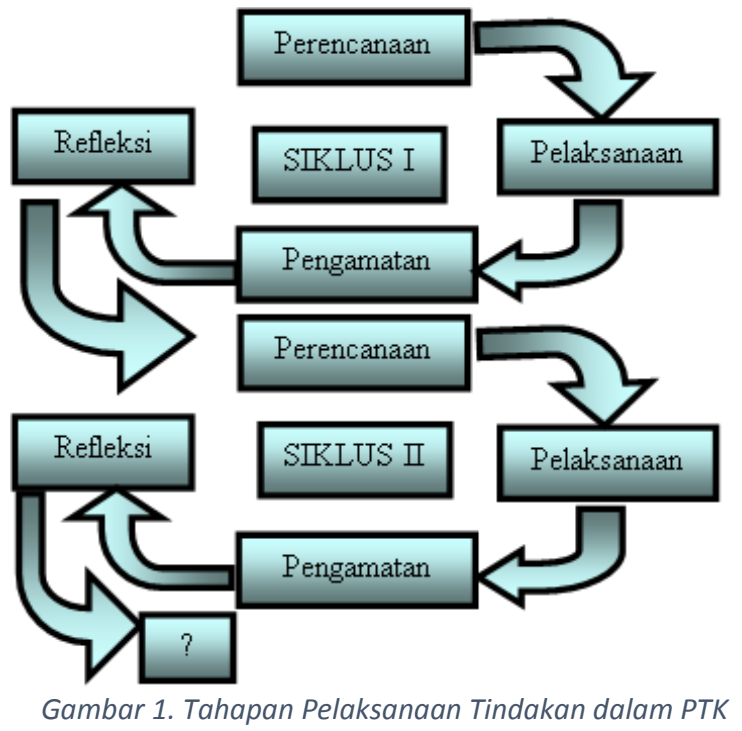

Alat pengumpulan data yang digunakan terdiri dari :

a. Lembar Observasi Anak

Digunakan pada saat kegiatan pembelajaran berlangsung, observasi terhadap siswa ini bertujuan untuk mengetahi bagaimana perkembangan motorik kasar anak dengan menggunakan permainan estafet.

b. Lembar Observasi Guru

Lembar observasi ini digunakan pada saat guru melaksanakan proses pembelajaran dengan menerapkan permainan estafet untuk meningkatkan motorik kasar pada anak.

Untuk melihat peningkatan hasil belajar anak tersebut dapat digunakan rumus untuk mencari rata-rata, dan persentasi ketuntasan belajar anak. Adapun rumus tersebut adalah sebagai berikut:

1. Nilai rata-rata

Peneliti menjumlahkan nilai yang diperoleh anak yang kemudian dibagi dengan jumlah anak yang ada di kelas yang diteliti sehingga diperoleh nilai rata-rata menurut (Aqib, dkk, 2011:204-205). Nilai rata-rata dapat dihitung dengan menggunakan rumus:

$$
\mathrm{X}=\frac{\sum X}{N}
$$

Keterangan:

$$
\begin{array}{ll}
\mathrm{X} & \text { : Nilai rata-rata } \\
\Sigma \mathrm{X} & \text { : Jumlah nilai } \\
\mathrm{X} & \text { : Jumlah siswa }
\end{array}
$$

Table 1. Kategori Skor Hasil Observasi

\begin{tabular}{ll}
\hline $\begin{array}{l}\text { Skor } \\
\text { Penilaian }\end{array}$ & Kriteria Penilaian \\
\hline $\mathbf{5}$ & Sangat Baik (SB) \\
\hline $\mathbf{4}$ & Baik (B) \\
\hline $\mathbf{3}$ & Cukup (C) \\
\hline $\mathbf{2}$ & Kurang (K) \\
\hline $\mathbf{1}$ & Kurang Sekali (KS) \\
\hline
\end{tabular}

Sumber (Aqib dkk 2009:41)

Untuk memudahkan pengelolaan data maka kriteria penilaian tersebut dimodifikasi sebagai berikut :

\begin{tabular}{ccc}
\hline $\begin{array}{c}\text { Skor } \\
\text { Penilaian }\end{array}$ & Interval & Kriteria Penilaian \\
\hline $\mathbf{5}$ & $4,6-5$ & Sangat Baik (SB) \\
\hline $\mathbf{4}$ & $3,6-4,5$ & Baik (B) \\
$\mathbf{3}$ & $2,6-3,5$ & Cukup (C) \\
\hline $\mathbf{2}$ & $1,6-2,5$ & Kurang (K) \\
\hline $\mathbf{1}$ & $0-1,5$ & Kurang Sekali (KS) \\
\hline
\end{tabular}

2. Ketuntasan Belajar Untuk menghitung persentase ketuntasan belajar digunakan rumus sebagai berikut: 


$$
P=\frac{F}{N} \times 100 \%
$$

Keterangan:

P : Keberhasilan anak didalam bermain peran

$\mathrm{F} \quad$ : Anak yang tuntas belajar

$\mathrm{N}$ : Jumlah frekuensi/keseluruhan

$100 \%$ : Nilai konstanta

(Aqib, dkk, 2009: 41)

Analisis ini dilakukan pada saat tahapan refleki. Hasil analisis ini digunakan sebagai bahan refleksi untuk melakukan perencanaan lanjutan dalam siklus selanjutnya. Hasil analisis juga dijadikan sebagai bahan refleksi dalam memperbaiki rancangan pembelajaran, bahkan dijadikan sebagai bahan pertimbangan dalam penentuan model pembelajaran yang tepat (Aqib, dkk, 2009: 41).

\section{HASIL DAN PEMBAHASAN}

Penelitian ini dilakukan untuk melihat bagaimana pelaksanaan permainan estafet dapat meningkatkan motorik kasar anak kelompok B Taman Kanak-kanak Lestari Desa Srikaton Blok V Kecamatan Pondok Kelapa Kabupaten Bengkulu Tengah yang dilakukan melalui dua siklus, dimana setiap siklus dilaksanakan tiga kali pertemuan, dimana dalam penelitian ini peneliti dibantu oleh dua orang teman sejawat. Adapun hasil dari penelitian yaitu melalui permainan estafet dapat meningkatkan motorik kasar anak.

Terbukti bahwa permainan estafet pada anak usia dini dapat meningkatkan motorik kasar melalui permainan estafet bola, lempar tangkap bola, dan menggiring bola dengan menggunakan variasi kelompok, kegiatan pertama setiap kelompok terdiri dari 4 oarang anak dan kegiatan kedua terdiri dari 5 orang anak. setiap kelompok membawa bola secara sambung menyambung dari start sampai finish, saat permainan estafet berlangsung dilakukan kompetisi secara kelompok, bagi kelompok yang berhasil memenagkan kompetisi diberikan pujian berupa semangat dan yang belum berhasil diberikan motivasi dan penguatan. Dalam permainan estafet ini adapun aspek motorik kasar yang diamati yaitu :

1. Kecepatan

Pada awal pertemuan aspek kecepatan sudah mencapai rata-rata tertinggi dibandingkan dengan aspek ketahanan, namun masih terdapat dua orang anak yang masih memperoleh nilai 2.5, hal ini dikarenakan anak masih belum memahami permainan dan masih merasa asing dengan kegiatan permainan estafet yang dilakukan, sehingga anak masih terlihat kaku dan tidak ingin mengikuti gerakan. Sehingga untuk rekomendasi pada pertemuan selanjutnya, guru harus lebih jelas lagi dalam memberikan contoh, serta guru juga harus memberikan penguatan, motivasi dan arahan, kepada anak seperti yang diungkapkan Maslow (Fadlillah,2012:125) yang menekankan bahwa pentingnya motivasi yang diberikan kepada anak karena motivasi didasarkan pada kebutuhan manusia yaitu kebutuhan akan harga diri dan kebutuhan aktualisasi diri, sehingga motivasi atau dorongan yang diperoleh dapat mendorong siswa untuk mencapai hasil belajar yang maksimal.

Setelah dilakukan perbaikan sesuai dengan rekomendasi pada pertemuan selanjutnya, pada aspek kecepatan mengalami peningkatan pada setiap pertemuan, peningkatan ini terjadi selain mengikuti rekomendasi pada pertemuan selanjutnya, peningkatan pada aspek kekuatan terjadi karena kegiatan permainan dilakukan secara berulang pada setiap pertemuan, sehingga anak sudah memahami dan mengerti tata cara dalam permainan.

Seperti yang diungkapkan Mudjiono (2009:46) dengan mengadakan 
pengulangan maka daya mengamat, menangkap, mengingat, mengkhayal, merasakan dan berpikir tersebut akan berkembang.

\section{Koordinasi}

Pada pertemuan pertama aspek ketahanan masih terdapat 4 orang anak yang memperoleh nilai 2 , hal ini dikarenakan anak masih terlihat kaku dan kurang mampu dalam mengontrol bola baik pada saat melempar maupun menagkap bola, serta pada saat menggiring dan menerima bola, hal ini dikarenakan anak masih merasa sulit dan kaku saat mengontrol bola. Namun, pada pertemuan selanjutnya setelah diberikan penguatan, contoh serta motivasi yang kuat dan pengulangan dalam setiap permainan, anak sudah mampu dan percaya diri dalam bermain estafet, seperti yang diungkapkan Hurlock (Suyadi,2010:69) ketika anak telah menunjukkan gerakan lentur badannya, maka gerakan kaki, tangan dan bahunya akan semakin bebas dengan eskperimen keterampilan-keterampilan baru, seperti melempar dan menangkap bola.

Kegiatan penelitian ini dilakukan di luar kelas, seperti yang diungkapkan Musfiroh (2009:1.32) ruang terbuka adalah tempat yang ideal untuk kegiatan stimulasi pengembangan motorik kasar. Kegiatan awal dilakukan dengan pembagian kelompok pada setiap anak, mengenal alat atau media yang akan digunakan dalam permainan, guru menjelaskan dan memberikan contoh permainan sehingga anak mengerti dan memahami tata cara permainan. Permainan dilakukan secara bervariasi pada setiap pertemuan dengan tujuan agar anak tidak mudah bosan dan jenuh. Ketika anak melakukan permainan peneliti memberikan semangat, dorongan, dan motivasi kepada anak saat berkompetisi serta setelah selesai melakukan permainan peneliti memberikan pujian dan respon positif setiap anak.
Dilihat dari hasil selama pelaksanaan permainan estafet untuk meningkatkan motorik kasar anak pada siklus I terdapat 1 orang anak (An) yang mengalami penurunan nilai dari pertemuan ke dua ke pertemuan ke tiga, hal ini dikarenakan An pada saat permainan dimulai An lebih banyak main-main dan tidak mengikuti aturan dalam permainan. Selain itu terdapat 11 orang anak (Ad, As, Ap, Ib, Ja, $\mathrm{La}, \mathrm{Ok}, \mathrm{Ik}, \mathrm{Mr}, \mathrm{Na}, \mathrm{Af}$ ) yang memperoleh nilai menetap, hal ini dikarenakan anak tidak bersemangat, anak sering tidak fokus dalam bermain, karena melihat temannya yang lain bermain-main, anak bermalasmalasan saat bermain, dan anak belum terlalu memahami permainan.

Pada siklus II terdapat 3 orang anak (Al, Ok, Af) yang nilainya masih menetap, hal ini dikarenakan anak tidak fokus saat bermain dan anak lebih banyak bermainmain.

Sedangkan anak-anak yang lainnya mengalami peningkatan nilai rata-rata, pada setiap pertemuan, hal ini dikrenakan anak-anak mampu fokus dan berkonsentrasi dalam bermain serta anakanak sudah memahami tata cara dalam permainan, selain itu kegiatan permainan juga dilakukan secara berulang pada setiap pertemuan, sehingga anak sudah memahami dan mengerti tanpa harus ada bimbingan dan bantuan dari guru atau peneliti. Anak pun terlihat percaya diri saat bermain dan berkompetisi untuk menjadi pemenang.

Pada dasarnya hampir seluruh anak mengalami peningkatan motorik kasar pada setiap aspek, hal ini terlihat pada setiap siklus, peningkatan ini terjadi dikarenakan guru terus memberikan motivasi, contoh permainan, serta anak juga sudah menguasai dan enjoy dalam bermain.

Seperti yang diungkapkan Sujiono (2010:73) mengemukakan bahwa pada dasarnya pembelajaran yang dipilih dan dipergunakan oleh guru harus bervariasidan 
menarik setiap perhatian anak sehingga anak mau melakukan kegiatan yang te;ah dirancang oleh guru. Salah satu pembelajaran yang menarik dan membangkitkan keaktifan anak dalam belajar adalah permainan estafet.

Untuk melihat peningkatan dan perbandingan seberapa besar peningkatan keberhasilan permainan estafet untuk meningkatkan motorik kasar anak, hal ini dapat dilihat dari hasil perhitungan yang menunjukkan bahwa terjadi peningkatan motorik kasar anak pada siklus I dan Siklus II yang dilakukan tiga kali pertemuan setiap siklusnya.

Berdasarkan uraian pembahasan di atas, dapat disimpulkan bahwa melalui permainan estafet dapat meningktkan motorik kasar anak pada anak kelompok B Taman Kanak-kanak Lestari Desa Srikaton Blok V Kecamatan Pondok Kelapa Kabupaten Bengkulu Tengah.

\section{KESIMPULAN}

Berdasarkan hasil penelitian yang telah dilakukan pada anak kelompok B Taman Kanak-kanak Lestari Desa Srikaton Blok V Kecamatan Pondok Kelapa Kabupaten Bengkulu Tengah dapat disimpulkan bahwa :

Motorik kasar anak meningkat dalam penelitian ini melalui proses permainan estafet bola, lempar tangkap bola, dan menggiring bola dengan menggunakan variasi kelompok. Dalam variasi kelompok kegiatan pertama setiap kelompok terdiri dari 4 orang anak dan kegiatan kedua terdiri dari lima orang anak. setiap kelompok membawa bola secara sambung menyambung dari start sampai finish, pada saat permainan estafet berlansung dilakukan kompetisi secara kelompok, bagi kelompok yang berhasil memenangkan kompetisi diberikan pujian berupa semangat dan yang belum berhasil diberikan motivasi dan penguatan.
Melalui permainan estafet dapat meningkatkan motorik kasar anak kelompok B Taman Kanak-kanak Lestari Desa Srikaton Blok V Kecamatan Pondok Kelapa Kabupaten Bengkulu Tengah, hal ini telihat dari hasil ketuntasan belajar anak secara klasikal pada siklus I sebesar $38.89 \%$ meningkat pada siklus II sebesar $88.89 \%$. peningkatan tersebut dapat dibuktikan pada hasil yang menunjukkan terjadinya peningkatan yang signifikan terhadap perkembangan motorik kasar antar siklusnya.

\section{DAFTAR PUSTAKA}

Aqib, Z., Diniati, E., Jaiyaroh, S., \& Khotimah, K. (2011). Penelitian Tindakan Kelas Untuk Guru SD, SLB, dan TK. Bandung: CV. Yrama Widya.

Arikunto, Suharsimi; Suhardjono; Supardi. (2008). Penelitian Tindakan Kelas. Jakarta : Bumi Aksara.

Bambang Sujiono, dkk. (2014). Metode Pengembangan Fisik. Tangerang Selatan: Universitas Terbuka

Bestari Nursih. (2014). Meningkatkan Motorik Kasar Melalui Permainan Sunda Manda. Dalam Skripsi (http://eprints.uny.ac.id/14653/1/SKRI PSI-BESTARI-NURSIH.pdf) Diakses pada tanggal 20 April 2016

Daeng Hans. (2009). Permainan Dalam Pembelajaran.

(http://belajarpsikologi.com/2014/12/1 5/metode-permainan-dalampembelajaran/.) Diakses pada tanggal 15 April 2016

Fadlillah, Muhammad. (2012). Desain Pembelajaran PAUD. Yogyakarta: Ar-Ruzz Media

Grafura Lubis, dkk. (2011). Permainan Edukatif Untuk Pembelajaran Atraktif. Jakarta: Prestasi Pustaka Publisher 
Hilrih. (2014). Jenis Permainan Anak Usia Dini. (http:/paud.smart:contoh-untukpermainan-anak-usia-

dini.com/2014/12/15/jenis-jenispermainan-untuk-aud/.) Diakses pada tanggal 15 April 2016

Nomifrod. (2016). Perkembangan Fisik Motorik Anak Usia Dini. (http://www.nomifrod.com/2016/08/p erkembangan-fisik-motorik-anak-usiadini.html) Diakses pada tanggal 14 April 2016

Peraturan Menteri Pendidikan dan Kebudayaan Republik Indonesia Nomor 137 Tahun 2014 Tentang Standar Nasional Pendidikan Anak Usia Dini.

Prawoto Agung. (2013). Upaya Meningkatkan Sosialisasi Melalui Bermain Estafet. Dalam Skripsi

(http://library.ikippgrismg.ac.id/docfiles/full text/bb84ccfcb960aeda.pdf)

Diakses pada tanggal 21 April 2016

Priatna Eri. (2008). Olahraga Atlektik.Jakarta: CV Sahabat

Richard Decaprio. (2013). Aplikasi Teori Pembelajaran Motorik Disekolah.Jakarta: Diva Press

Roman Mohandas, Dkk. (2014). Buku Panduan Pendidik Kurikulum 2013 PAUD Anak Usia 5-6 Tahun. Jakarta : Pusat Kurikulum dan Pembukuan

Sudijono Anas. (2012). Pengantar Statistik Pendidikan. Jakarta : Raja Grafindo Persada

Sugiyono. (2011). Metode Penelitian Pendidikan. Bandung: Alfabeta

Sumarya, dkk. (2010). Pendidikan Jasmani Olahraga dan kesehatan. Jakarta : PT. Arya Duta
Sunarsih Sri, dkk. (2007). Penjas Orkes. Jakarta : Erlangga

Wagino, dkk. (2010). Pendidikan Jsmani Olahraga dan Kesehatan. Jakarta: CV Bina Pustaka

Wahyudin, Din dkk. (2006). Pengantar Pendidikan. Jakarta : Universitas Terbuka

Wardani, I.G.A.K. dkk. (2007). Penelitian Tindakan Kelas. Jakarta: Universitas Bengkulu

Yuliani Nurani Sujiono. (2011). Konsep Dasar Pendidikan Anak Usia Dini. Jakarta: PT Indeks 